\title{
Studi Tentang Pembenaran Dalam Kristus Menurut Roma 5:1-11
}

\author{
Widarty Hetmina \\ Sekolah Tinggi Teologi Pelita Dunia, Tangerang \\ hetminawidarty@gmail.com
}

\begin{abstract}
In the discussion of this article the author concentrates on justification in Christ according to Romans 5: 1-11. Since the doctrine of justification means God's act of taking away the sinner's sin and counting him to be righteous, it is a free act on His part by His grace, through faith in Christ Jesus, not based on the person's virtue, but because Jesus shed His blood on behalf of people that, which was done for the fulfillment of the law to represent and to save him.
\end{abstract}

Keywords: Justification, Christ, Faith

Abstrak: Pembahasan artikel ini penulis konsen membahas tentang Pembenaran Dalam Kristus Menurut Roma 5:1-11. Karena doktrin pembenaran berarti tindakan Allah untuk menghapus dosa orang berdosa dan memperhitungkan dia benar, ini tindakan bebas dari pihak-Nya oleh kasih karunia-Nya, melalui iman dalam Kristus Yesus, bukan berdasarkan kebajikan orang itu, tetapi karena Yesus menumpahkan darah-Nya demi orang itu, yang dilakukan demi penggenapan hukum Taurat untuk mewakili dan untuk menyelamatkan dia.

Kata kunci: Pembenaran, Kristus, Iman

\section{Pendahuluan}

Secara Alkitabiah, pembenaran adalah "dipandang benar" di hadapan Tuhan. Ketika seseorang "benar", maka dia "tidak berdosa”, "tanpa kesalahan", atau "tidak bersalah" di hadapan Tuhan. Orang yang benar adalah "dipandang benar" di hadapan Tuhan. Alasan yang mendasari Rasul Paulus mengenai doktrin pembenaran. berdasarkan latar belakang Perjanjian Lama, yakni yang dijelaskan oleh Ladd dalam bukunya yaitu:"tsedeq,tsedage" artinya orang yang benar (tsaddiq) adalah manusia yang mematuhi aturan yang ada. Kata kerja "menjadi benar" (tsadaq) berarti mematuhi aturan yang ada, dan dalam bentuk tertentu, berarti "menyatakan benar" atau 'membenarkan.

Secara umum, dalam Kamus Bahasa Indonesia "pembenaran merupakan proses, perbuatan atau cara membenarkan". ${ }^{1}$ Artinya seseorang yang didapatkan melakukan kesalahan diadili supaya mendapatkan pernyataan benar atau salah dari pribadi orang tersebut. Dan hal ini juga ada di dalam dunia kekristenan agar dapat menyatakan perbuatan-perbuatan dari pribadi orang percaya yang menunjuhkan apakah orang tersebut layak atau tidak. Namun tidak semudah hal tersebut diterapkan dalam kekristenan sebab banyak terjadi pertikaian di antara gereja-gereja

\footnotetext{
${ }^{1}$ Fahmi Idrus, Kamus Lengkap bahasa Indonesia, (Surabaya: Greisinda Press), 88.
} 
Tuhan saat ini maupun sudah terjadi pertikaian mengenai pembenaran oleh karena iman sejak tahun 1500-an hingga saat ini.

Pembenaran tidak menjadikan seseorang benar, tetapi hanya menyatakan seseorang itu benar di hadapan Allah. Di dalam Alkitab terdapat 29 kali kata pembenaran ini di tulis dalam surat-surat Paulus khususnya dalam Roma 4:25;5:18 mengandung kata benda yaitu dikaiosis (dikaiosis). Pengertian pembenaran menjadi dasar ajaran tentang penyelamatan manusia.

\section{Metode Penelitian}

Pada penelitian ini, penulis atau peneliti menggunakan pendekatan atau metode kualitatif untuk memperoleh data yang valid guna membangun sebuah teori yang berkaitan dengan tema atau pokok penelitian. Metode kualitatif yang dimaksud adalah mengkaji dan mengelaborasi setiap sumber, informasi dan data-data yang diperoleh dari pustaka.

\section{Hasil dan Pembahasan}

\section{Studi Tentang “Pembenaran Di Dalam Kristus” Menurut Kitab Roma 5:1-11}

\section{Interpretasi Literal}

Literal berarti terjemahan harafia. Di dalam penafsiran ini, penulis akan mencari maksud kata "pembenaran" dalam Kristus secara harafia yaitu sesuai dengan arti yang biasa. Dalam Alkitab mempunyai arti biasa atau arti normal, kecuali konteks yang menuntut kata itu mempunyai arti yang luar biasa. Untuk melihat secara literal, dalam kamus ensiklopedi yang akan menolong untuk memberikan pengertian harafiah dari kata ini.

Jadi dalam meneliti kata pembenaran, yang kata dasarnya benar dalam kamus bahasa Indonesia kata benar itu berarti sesuai sebagai mana adanya (seharusnya); betul tidak salah: apa yang dikatakannya itu, adil , tidak berat sebelah, kemudian kata dasar berubah menjadi kata kerja "membenarkan"artinya membuat supaya benar, meluruskan, membetulkan, memperbaiki, menyatakan benar, mengiakan, menganggap benar. ${ }^{2}$ Jadi dari hasil penyelidikan diatas dapat disimpulkan bahwa arti "Membenarkan" secara literal adalah merupakan tindakan Allah sebagai hakim untuk membenarkan manusia dari setiap kesalahan yang diperbuatnya.

Dan makna kata dikaiooitu dari latar belakang orang Yahudi dan Hilenisme, khususnya dalam penggunaan kata ini mempunyai makna bahwa "untuk memberikan keadilan bagi seseorang yang dinyatakan bersalah dan menjadikan orang tersebut benar di hadapan Tuhan."3 Jadi kata membenarkan dapat di definisikan sebagai tindakan bahwa Allah membenarkan manusia dari setiap kesalahan yang diperbuatnya.

\footnotetext{
${ }^{2}$ Kamus Besar Bahasa Indonesia

${ }^{3}$ Geoffrey W. Bromiley, Theological Dictionary of the New Testament, (Germany: British Library cataloguing in Publication Data, 1992), 175.
} 
Dalam bukunya, George Eldon Ladd mengatakan bahwa kata kerja "membenarkan" adalah dikaioo, yang terbentuk dari akar kata yang sama dengan benar (dikaios) dan kebenaran (dikaiosune). Hal ini dinyatakan oleh dikaioo adalah "menyatakan benar" bukan "membuat atau menjadikan benar" 4 doktrin tentang pembenaran merupakan hal yang sangat penting yang di tulis oleh Rasul Paulus, kata kerja membenarkan atau dikaioo terdapat empat belas kali dan kata kebenaran atau dikaiosune terdapat lima puluh dua kali yakni ada dalam surat Roma dan Galatia.

\section{Interpretasi Kontekstual}

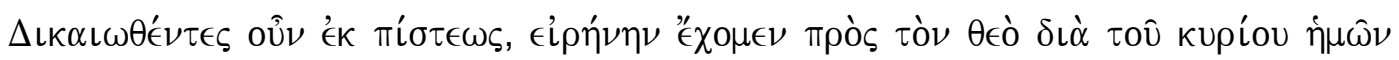
'I kuriou hemon Iesou Kristou). Dalam lembaga Alkitab Indonesia (LAI) menerjemahkan secara kontekstual "sebab itu, kita yang dibenarkan karena iman, kita hidup dalam damai sejahtera dengan Allah oleh karena Tuhan kita Yesus Kristus. Terjemahan ini bersifat umum dan tidak menunjukkan kepada jenis oknum yang pasti, dalam kitab bahasa asli Yunani.

Para sarjana mencoba mengusulkan satu topik yang bisa memayungi pasal 58. Cranfield menganggap bahwa "bagian ini sebagai elaborasi lanjutan dari ayat 17 "orang yang benar oleh iman akan hidup". 1:18-4:25 menjelaskan "orang yang benar oleh iman", sedangkan 5:1-8:39 menjelaskan "akan hidup". Bagian 5:1-8:39 diberi tema "Kehidupan yang dijanjikan bagi mereka yang dibenarkan oleh iman". Pembagian ini bisa dibenarkan dari segi isi 1:18-4:25 dan 5:1-8:39, meskipun penggunaan kutipan Perjanjian Lama di ayat 17 sebagai dasar masih bisa dipertanyakan. Bagaimanapun, pembagian Cranfield masih bisa dibuat lebih spesifik. Fokus khusus dalam pembahasan pasal 5-8 adalah kepastian/jaminan keselamatan. Hal ini tampak dari 5:1-11 dan (terutama) 8:18-39. Orang yang sudah dibenarkan oleh iman memang masih mengalami berbagai tantangan, namun tantangan tersebut tidak akan membahayakan keselamatan orang percaya. Orang percaya tidak perlu kuatir tentang maut sebagai implikasi dosa Adam (pasal 5), dosa (pasal 6), Taurat (pasal 7) maupun penderitaan jaman ini (pasal 8).

Secara umum dapat dikatakan bahwa para teolog menyetujui bahwa Roma 5:1-11 berbicara tentang hasil pembenaran, namun mereka belum mencapai konsensus tentang hasil spesifik yang dimaksud Paulus. Ada dua usulan yang sangat mungkin menjadi inti 5:1-11: damai dengan Allah atau kepastian pengharapan.

\section{Eksegesis studi kata}

Pasal 5:1-2. Frase kata dikaiwqe,ntej [participle] ou en evk pi,stewj (EV's "being therefore justified by faith") merupakan rangkuman dari pembahasan tentang pembenaran oleh iman di 1:18-4:25. Frase ini diikuti oleh tiga kata kerja indikatif yang menunjukkan hasil dari pembenaran tersebut, meskipun dari segi sintaks dua kata kerja terakhir posisinya tidak sepenting kata kerja pertama.

\footnotetext{
${ }^{4}$ George Eldon, ibid, 186

${ }^{5}$ http.www.members.tripod.com
} 
Pertama, Orang percaya memiliki damai dengan Allah (ay. 1).Arti kata "damai"

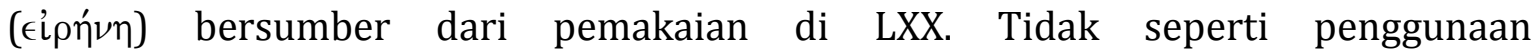
kata eivrh,nh (eirene)di literatur Yunani sekuler yang hanya mengindikasikan

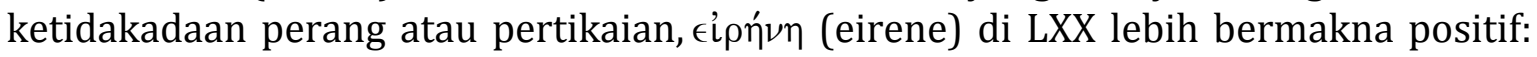
kemakmuran, kesejahteraan dan keselamatan orang benar. Yang lebih penting adalah penggunaan kata erene (erene) oleh para nabi untuk menggambarkan keselamatan yang akan dilakukan Allah di akhir zaman (Yesaya 54:10; Yeremia 37:26; (Yesaya 54:10; Yeremia 37:26; Yehezkiel 34:25).

Kedua, Orang percaya memiliki akses ke anugerah (ay. 2a). Dalam terjemahan NASB menerjemahkan prosagwgh,(prosagoge) (LAI:TB "jalan masuk") dengan "introduksi". Terjemahan ini menyiratkan proses masuk yang pertama (initial entry) tanpa menjelaskan kontinuitas proses tersebut. Bagaimanapun terjemahan mayoritas EV's "akses" lebih bisa diterima. Penggunaan tense perfect pada kata "memiliki" ('́ $\sigma \chi \eta ́ \kappa \alpha \mu \epsilon \nu$; LAI:TB "beroleh") mengindikasikan penekanan pada kontinuitas suatu tindakan. Di tempat lain Paulus juga menggunakan kata $\pi \rho \circ \sigma \alpha \gamma \omega \gamma \eta$, untuk kondisi kekinian orang percaya (Efesus 2:18; 3:12). Selain itu,

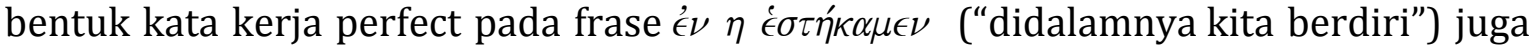
mendukung ide kontinuitas.

Kata "anugerah" (caris; LAI:TB "kasih karunia") bisa merujuk pada pemberian Allah (11:5-6), tindakan Allah $(5: 15,17)$, dan lain-lain. Dalam ayat ini caris (kharis) tampaknya merujuk pada domain (state atau realm). Terjemahan ini didukung oleh frase "dalam kasih karunia kita berdiri" di ayat 2a.

Ketiga, Orang percaya bersukacita dalam pengharapan tentang kemuliaan Allah (ay. 2b). Memiliki kemuliaan Allah yang dulu kurang (Roma 3:23) memang baru akan dinikmati di masa yang akan datang, namun sukacita pengharapan tersebut bisa dirasakan sekarang. Pembenaran yang Allah kerjakan dalam diri manusia merupakan suatu pembenaran yang mutlak dari diri Allah yang dinyatakan dalam kehidupan manusia yang berdosa.

Kata "iman" yang dipakai dalam Perjanjian Baru merupakan terjemahan dari

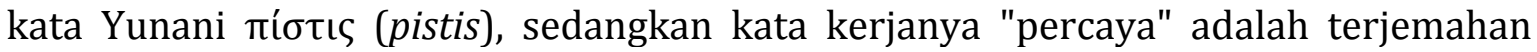

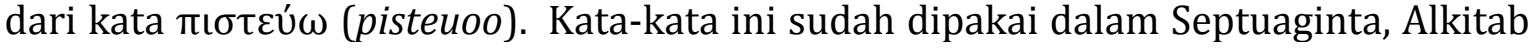
Ibrani (Perjanjian Lama) dalam bahasa Yunani, sebagai terjemahan kata Ibrani am' (aman), yang berarti keadaan yang benar dan dapat dipercayai/diandalkan.

Dalam surat Roma pasal 5 yang merupakan bagian kedua yang terbesar dari surat Roma, yang merupakan kitab terstruktur, dalam Roma 1:8 merupakan pembukaan bagian pertama dari surat Roma yang menyatakan tentang murka Allah. Murka Allah berubah menjadi damai sejahtera dengan Allah bukanlah sesuatu yang otomatis melainkan harus ada yang dibayar. Dalam Roma 3:21-24 yang mengatakan: tetapi sekarang, kita yang berdosa dibenarkan dengan cuma-Cuma karena penebusan dalam Kristus Yesus. Dalam hal ini ada harga yang harus dibayar untuk menebus manusia dari dosa, yakni melalui kematian Yesus Kristus sehingga dapat mendamaikan manusia yang berdosa.

\section{Interpretasi Gramatikal}


Dalam penelitian gramatikal ini, akan mencari maksud dari kata "pembenaran' dengan melihat tata bahasanya. Untuk dapat membandingkan tulisan Rasul Paulus dengan tulisan Yakobus mengenai pembenaran menunjuhkan perbedaan yang tegas tentang isi dan cara penyajiannya. Anugerah merupakan sebuah pokok pembahasan yang penting dalam surat Roma dan konsep mengenai Anugerah berkaitan erat dengan konsep pembenaran.Sejak awal Paulus sudah menggunakan kata ini sebagai sebuah salam pembuka (1:7). Lebih lanjut, di sepanjang surat Roma, Paulus juga berulang-ulang menyebut dan mengajarkan tentang anugerah Allah, baik dalam hubungan dengan panggilan kerasulannya oleh Kristus (1:5) maupun dalam hubungan dengan keselamatan.

\section{Interpretasi Theologis}

Pembenaran merupakan doktrin yang menjadi dasar dalam kekristenan, yang didalamnya mengenai pengampunan Allah kepada orang yang berdosa. Rasul Paulus menekankan doktrin pembenaran oleh iman merupakan sebuah eksposisi analitis dari fakta di dalam konteks yang penuh dengan teologis. J I Packer, mengatakan bahwa "doktrin pembenaran menentukan menentuk karakter seluruh iman kekristenan". ${ }^{6}$

Secara Alkitabiah atau theologis, "pembenaran dari bahasa Ibrani yaitu sadeq, sedangkan dalam bahasa Yunani yaitu dikaioo (dikaioo) yang artinya membenarkan dari akar kata yang sama dengan benar yakni dikaios (dikaios) dan kebenaranyaitu dikaiosune (dikaiosune)." 7 Jelas bahwa Allah yang di sembah oleh orang percaya adalah Allah yang benar, yang memiliki kebenaran yang mutlak oleh sebab itu sebagai orang percaya pun harus hidup dalam kebenaran yang telah dinyatakan oleh Allah.

Doktrin pembenaran, baik dalam bahasa Ibrani dan bahasa Yunani memiliki akar kata yang sama yang diterjemahkan ke dalam Alkitab bahasa Inggris sebagai "righteousness" dan "justification" atau "pembenaran." Di dalam bahasa Ibrani kata ini diterjemahkan dari kata tsedeq. Tsedeq berarti "dijadikan benar" yang juga berarti "dinyatakan benar" atau "justifikasi/pembenaran." Dalam Kejadian 5:6 seperti dikutip dalam Galatia 3:6, "Secara itu jugalah Abraham percaya kepada Allah maka Allah memperhitungkan hal itu kepadanya sebagai kebenaran." Kata "kebenaran" seperti terdapat dalam Kejadian 6:15 berasal dari bahasa Ibrani yaitu bentuk substantif dari kata tsedeq yang berarti "righteousness" atau "kebenaran." Jadi di sini iman Abraham di perhitungkan sebagai kebenaran. Sedangkan dalam kata bahasa Yunani, khususnya dalam Galatia 3:6 ini menggunakan kata dikaios yang berarti "dijadikan benar." Dalam Matius 1:19, "Yusuf disebut orang benar" atau dalam terjemahan bahasa Indonesia di sebut "tulus hatinya." Di dalam Matius 5:45 dikatakan bahwa "Tuhan menurunkan hujan bagi orang benar atau dikaios dan orang yang tidak benar atau adikos." Dalam Kisah Para Rasul 10:22, "Kornelius seorang perwira yang tulus hati atau dikaios." Dalam Roma 1:17 dikatakan bahwa "orang benar atau dikaios akan hidup oleh iman." Bentuk verbal dari kata dikaios adalah dikaioo yang berarti "menyatakan kita benar." Pemungut cukai yang berdoa di Bait Suci pulang ke rumahnya dengan dikaioo atau "dinyatakan

\footnotetext{
${ }^{6}$ J.I Packer, Evangelical dictionary of Theologi

${ }^{7}$ Ladd eldon, teologi perjanjian baru (Bandung: Kalam Hidup, 1999), 186
} 
benar". Dalam Roma 8:30 dikatakan "dan mereka yang dipanggil-Nya, mereka itu juga di benarkan-Nya (edikaisomen) dan mereka yang dibenarkan (edikaisomen) mereka itu juga dimuliakan-Nya." Bentuk substantif yang lain dari kata kerja Yunani adalah dikaiosis yang berarti "pembebasan atau pembenaran." Dalam Roma 4:25, dikatakan bahwa "Yesus yang telah diserahkan karena pelanggaran kita dan dibangkitkan karena pembenaran (dikaiosis) kita." Kata yang sama juga digunakan di dalam Roma 5:18, "Sebab itu sama seperti oleh satu pelanggaran semua orang beroleh penghukuman demikian pula oleh satu perbuatan kebenaran semua orang beroleh pembenaran (dikaiosis) untuk hidup." Jadi kata "justifikasi" atau "pembenaran" berarti "dinyatakan benar atau dijadikan benar."

Kematian Yesus Kristus mendamaikan orang percaya dengan Allah (ay. 10) sebab jika ketika kita musuh, kita didamaikan dengan Allah melalui kematian AnakNya, maka berapa banyak lagi, karena telah didamaikan maka kita akan telah diselamatkan oleh hidupnya". Artinya bahwa orang percaya ketika masih dalam keadaan sebagai musuh Allah tetapi mengasihinya, jauh lebih berharga jika orang percaya itu benar-benar hidup dalam kebenaran berarti Allah lebih mengasihinya.

\section{Interpretasi Theologikal}

Kata membenarkan memiliki pengertian dalam bahasa Indonesia, yaitu secara etimologi teologi, kebenaran memilki kata dasar benar. Kamus bahasa Indonesia memberikan beberapa pengertian dari kebenaran: "keadaan yang cocok dengan fakta atau hal yang sebenarnya, sesuatu yang sungguh-sungguh (benar-benar ada, suara hati, kejujuran, izin, persetujuan, perkenan, dan sebetulnya). Yesus adalah kebenaran itu. Yesus membenarkan orang-orang berdosa untuk layak masuk kerumah Bapa. Membenarkan berarti menyatakan benar atau menghapus setiap kesalahannya. Sedangkan istilah pembenaran dari kata kerja membenarkan mempunyai arti masuk kedalam suatu hubungan atau kondisi yang benar dengan Allah atau dapat diartikan dengan arti yang lain yakni dijadikan benar di hadapan Allah. Pembenaran merupakan pemberian Allah yang rahman dalam Alkitab selalu terkait dengan iman dan anugerah dan tidak pernah dengan tindakan apa pun yang orang berdosa dapat lakukan (Rm 4:16). Sebalinnya, sebaliknya Rasul Paulus menekankan perbedaan yang sangat besar antara pencobaan dan pembenaran dengan usaha manusia dan pembenaran yang diterima "oleh karena iman dalam Kristus Yesus" (Gal 2:16).

Maka sangat jelas bahwa pembenaran Alkitabiah berkaitan dengan anugerah dan iman bukan karena usaha manusia. Melalui surat Rasul Paulus khususnya melalui surat Roma, sangat memberikan pengaruh yang positif dan membawa pertobatan yang luar biasa, khususnya dalam pribadi Marten Luther. Dalam Roma 1:17, Rasul Paulus menulis "kebenaran Allah" yang dimaksudkan Paulus disini "bukanlah keadilan Tuhan yang bersifat menghukum yang membuatNya menghukum orang berdosa, melainkan kebenaran yang Tuhan berikan kepada orang berdosa yang membutuhkan dan orang berdosa itu terima dengan iman." 8 hal ini merupakan kebenaran yang sempurna yang tidak bercacat, didapatkan oleh Kristus yang dengan kemurahan Tuhan di berikan kepada semua orang percaya. Selain itu juga, Martin Luther berkata bahwa "doktrin pembenaran adalah doktrin yang olehnya Gereja berdiri atau jatuh. Doktrin ini merupakan kepala dan juga baru penjuru Gereja yang

\footnotetext{
${ }^{8}$ Anthony Hoekema, Saved by Grace (Grand Rapids, M1: B.Eerdmans Co., 1989), 380
} 
melahirkan, memelihara, membangun dan melindungi Gereja. Tanpanya Gereja tidak dapat bertahan hidup". 9 Artinya bahwa setiap orang percaya hidup sesuai dengan kehendaknya sendiri tanpa memandang kepada Tuhan maka hidupnya tidak akan bertahan untuk selamanya. Jadi doktrin pembenaran sangat penting dalam bagi iman Kristen, sebab memiliki hubungan dengan keselamatan yang akan dinyakan oleh Allah kepada orang percaya. Oleh sebab itu orang percaya harus mengerti juga doktrin tentang keselamatan atau soteriology. Sehingga dengan begitu orang percaya tidak dapat dengan muda diperdaya oleh ajaran-ajaran yang menyimpang dari kebenaran Firman Tuhan. Dengan demikian orang percaya akan menjadi pribadi yang kokoh dan memiliki iman yang tangguh di dalam Kristus.

\section{Interpretasi Historis}

Konteks historis adalah penting sebagai suatukerangka dimana menafsirkan kitab suci, setiap kitab, dan dalam setiap kitab ditulis dalam suatu konteks historis yang harus dimengerti supaya dapat menolong menafsirkan kitab itu dengan akurat."10 Berbicara soal pembenaran ada kaitanya dengan anugerah yang Allah kerjakan dalam kehidupan orang percaya. Kata "anugerah" berasal dari istilah kharis (kharis) yang diterjemahkan sebagai "kasih karunia".11

Di dalam Perjanjian Baru kata ini bermakna, "kemurahan hati Allah yang tidak pantas diterima oleh orang yang layak dihukum".Istilah ini dipakai untuk mengungkapkan sikap Allah yang menyediakan keselamatan bagi manusia.Dengan demikian keselamatan bukan berdasarkan kebaikan manusia tetapi semata-mata berdasarkan kehendak Allah sendiri.Anugerah merupakan ciri utama dalam teologi Rasul Paulus. Rasul Paulus dalam Surat Roma mengatakan bahwa manusia yang berdosa "telah diselamatkan dengan cuma-cuma melalui anugerah" (Rm 4:16).Akan tetapi, manusia harus merespons anugerah Allah tersebut bagi dirinya sendiri melalui iman.Melalui penjelasan tersebut, disimpulkan bahwa "karena anugerah oleh iman" (Efesus 2:8), maka manusia diselamatkan. Rasul Paulus menghubungkan konsep anugerah Allah itu dengan Taurat.Menurut Rasul Paulus, Taurat juga mengungkapkan anugerah Allah (Roma 7:12).Anugerah Allah menggenapi apa yang tidak dapat diperbuat oleh manusia melalui Taurat.Persamaan antara anugerah dan Taurat adalah keduanya merupakan suatu sarana keselamatan dari Allah. Selain itu juga di dalam Perjanjian Lama memberikan penjelasan mengenai latar belakang anugerah itu di berikan kepada manusia.

Salah satu wujud kasih karunia Allah yang tergambar di dalam Perjanjian Lama adalah tawaran pendamaian atas pelanggaran manusia dalam kisah penciptaan. Kisah ini dimulai dengan gambaran bumi kacau dan belum terbentuk. Keadaan gelap dan kekacauan ini menunjukkan situasi yang jauh dari Allah. "Dalam keadaan kacau, Allah menunjukkan kesediaan dan inisiatif untuk memberi rupa dan bentuk kepada langit dan bumi."12 Akibatnya, dunia mulai teratur, teduh, tenang, dan damai.Allah melihat bahwa apa yang diciptakannya baik dan sungguh amat baik (Kej. 1: 4,10, 12,18,21,25 dan 31). Langit dan bumi yang kacau diganti dengan langit dan bumi

\footnotetext{
${ }^{9}$ Sinclair Ferguson, The Cristian Life: A Doctrinal Introduction (Carlisle, P A: Banner of Truth Trust, 1989), 80

${ }^{10}$ Enss, The Moody Hand Book of Theology, 214

${ }^{11}$ Donald Guthrie, Teologi Perjanjian Baru II. Jakarta: BPK Gunung Mulia. 270

${ }^{12}$ Hakh, Samuel Benyamin. 2009. Damai Itu Meneduhkan. Bandung: Jurnal Info Media. 12
} 
yang shalom Allah memiliki inisiatif (Allah sebagai inisiator) untuk menciptakan keteraturan dan relasi yang harmonis dengan seluruh ciptaan.Pendamaian juga terdapat dalam perjanjian antara Nuh dan Allah setelah peristiwa Air Bah. Di dalam Alkitab disebutkan bahwa air bah ini merupakan hukuman atas kejahatan manusia yang hidup pada zaman Nuh. Setelah penghukuman itu, Allah berinisiatif untuk melakukan pendamaian dengan alam semesta melalui Nuh.Pendamaian ini menjadi tanda dimulainya babak baru dalam kehidudupan manusia.

Martin Luther (1483-1546) menyebut doktrin justification by faith alone sebagai dasar di mana kelangsungan atau kehancuran Gereja dipertaruhkan (articulus stantis et cadentis ecclesiae). Kurang dari seratus tahun kemudian, Francis Turrentin (1623-1687), seorang pastor and profesor theologi di Geneva, memperingatkan Gereja agar tetap setia mengajarkan doktrin ini secara jelas dan akurat karena penyelewengan atas doktrin ini pasti mengakibatkan penyelewengan yang lebih lanjut akan doktrin-doktrin lainnya dan Iblis pasti selalu berusaha dengan segala cara untuk menggeser perhatian Gereja akan pentingnya mengajarkan doktrin ini. Yang menjadi pertanyaan adalah mengapa doktrin ini begitu penting bagi Gereja? Apakah yang dicatat oleh Alkitab mengenai doktrin ini? Serta bagaimana sejarah keKristenan mencatat perkembangan doktrin ini?Development of the Doctrine in Church History.

Doktrin justification by faith alone sudah diajarkan secara tersirat dalam tulisan-tulisan bapa-bapa Gereja mula-mula, dan hingga abad ke-16 barulah Gereja menjawab panggilan untuk menggali kebenaran doktrin pembenaran secara lebih akurat dan jelas dari Alkitab. Pelagius (354-420) mengajarkan bahwa manusia diciptakan Allah tanpa mewarisi dosa turunan (original sin). Akibat dari pemahaman doktrin dosa yang salah ini, Pelagius sampai pada kesimpulan yang begitu menyimpang dari Alkitab, yaitu manusia dimungkinkan untukmemperoleh keselamatan melalui upaya perbuatan baik dan menjalankan perintah-perintah agama. Pelagius menolak akan keabsolutan anugerah Allah di dalam Kristus melalui iman yang memimpin kepada keselamatan pribadi. Ajaran Pelagius (Pelagianism) ini akhirnya dinyatakan sebagai ajaran sesat oleh tiga sidang Gereja: Synod of Carthage, Council of Ephesus, dan Synod of Orange.

Agustinus (354-430) melawan ajaran Pelagius karena tidak sesuai dengan ajaran Alkitab. Ia memakai starting point yang sangat berbeda dengan Pelagius. Natur manusia adalah natur yang berdosa akibat dosa turunan Adam sehingga tidak mungkin untuk melakukan perbuatan-perbuatan baik di mata Allah yang suci. Oleh karena itu manusia membutuhkan anugerah spiritual dari Roh Kudus yang mencerahkan akal budi manusia, mengubahkan hati manusia untuk mencintai hal-hal yang kudus, menumbuhkan iman, dan memungkinkan manusia untuk berbuat baik. Menurut Agustinus, iman di dalam Kristuslah yang membenarkan orang berdosa. Manusia berdosa dibenarkan oleh darah Kristus yang dialirkan di atas kayu salib untuk menggantikannya. Anugerah ini diberikan oleh Allah secara bebas sesuai dengan kedaulatan Allah dan tidak tergantung kepada jasa perbuatan baik manusia. Jadi bisa dilihat bahwa anugerah Allah mendahului perbuatan baik manusia.

Di dalam konsepjustification-nya, Agustinus mencampuradukkan doktrin pembenaran (justification) dengan doktrin pengudusan (sanctification). Menurutnya di dalam membenarkan orang berdosa, Allah tidak mendeklarasikan orang 
berdosa sebagai orang benar tetapi membuat pendosa itu menjadi orang benar. Kegagalan Agustinus dalam membedakan secara jelas dan akurat mengenai doktrin pembenaran dan pengudusan ini kemudian diwariskan kepada theolog-theolog Gereja setelahnya.

Thomas Aquinas (1225-1274) mengembangkan doktrin justification yang telah diajarkan oleh Agustinus. Menurutnya, pembenaran oleh Allah bekerja melalui anugerah pengudusan yang diinfusikan ke dalam jiwa manusia oleh Allah sehingga mengubah orientasi kehendak bebas manusia untuk pertama-tama taat kepada Allah, dan kemudian melawan dosa, serta akhirnya menghasilkan pengampunan dosa. Aspek pengudusan menjadi lebih jelas dan sistematik di dalam konsep justification yang diajarkan oleh Thomas Aquinas dan menjadi ajaran resmi gereja Katolik Roma sampai dengan abad ini.

Secara geografis, kota Roma didirikan tahun 753 sM, di tujuh bukit, diatas jurang tebing dimana tanah daratan latin bertemu dengan sungai Tiber, tempat penyebrangan pertama di muara. Kota Roma adalah tempat bertemu dan bercampurnya bangsa-bangsa, bukan tempat tinggal satu bangsa."13 Dan juga pada masa Paulus kota Roma sangat penting. Rasul Paulus sendiri menyatakan betapa kuat keinginannya untuk memberitakan Injil di sana. Rasul Paulus menyadari "pentingnya peranan jemaat Kristen di pusat kerajaan Romawi itu dan, boleh jadi hal ini dipengaruhi oleh surat Roma."14

Pendapat Rasul Paulus pada saat melayankan pandangan teologisnya kepada jemaat Roma merupakan sesuatu hal yang dianggap terpiji dalam surat Roma dilestarikan bagi generasi selanjutnya ajaran mulia dari sekristenan yang dengan tepat dihormati dan dalam teologi Kristen.

Masalah hostoris diatas menolong untuk meneliti dan melihat tentang cara orang Roma memandang pembenaran, yang Allah kerjakan dalam kehidupan orang percaya. Jadi Yesus Kristus merupakan jalan pendamaian yang Allah nyatakan, tanpa Kristus orang tidak bisa berhubungan dengan Allah. Oleh sebab itu satu-satunya jalan untuk memperoleh keselamatan hanya ada di dalam Kristus Yesus.

\section{Kesimpulan}

Dalam pandangan Augustinus dan Thomas Aquinas mengenai pembenaran oleh karena iman tidak jauh berbeda, disebabkan karena keduanya memberikan pandangan yang sama bahwa orang percaya dibenarkan oleh karena karya Allah semata dalam kehidupan orang percaya.

Dalam pandangan kaum protestan mengenai iman, diakibatkan oleh pandangan dari Gereja Katolik Roma. Pandangan ini dipelopori oleh Martin Luther yang merupakan tokoh reformasi yang memiliki semangat untuk mengeluarkan surat keputusan yang memiliki kaitannya dengan pembenaran oleh karena iman. Sehingga kaum Protestan mengakui bahwa pembenaran merupakan inisiatif dari Allah, bukan oleh karen usaha manusia. Dan juga pandangan Protestan mengakui bahwa iman merupakan alat yang menyebabkan pembenaran. Dengan demikian iman merupakan

\footnotetext{
${ }^{13}$ Ensiklopedi Alkitab Masa Kini, 321.

${ }^{14}$ Ibid. 324
} 
alat dimana karya Kristus teraplikasi dalam diri orang percaya. Iman yang digambarkan adalah iman yang hidup bukan pengakuan yang kosong. Iman merupakan kepercayaan yang bersifat pribadi yang bergantung kepada Kristus saja untuk keselamatan. Iman yang menyelamatkan juga merupakan iman pertobatan yang menerima Kristus sebagai Juruselamat dan Tuhan.

Untuk umat Katolik meyakini pembenaran oleh iman setelah munculnya gerakan yang dipelopori oleh Martin Luther. Katolik mengakui pembenaran oleh karena iman merupakan karya Roh Kudus dalam kehidupan umat manusia. Selain itu juga umat Katolik menekankan mengenai pertobatan dan penyucian hidup. Tetapi semuanya itu merupakan karya Allah melalui Roh Kudus dalam kehidupan orang percaya.

Selain itu juga, pandangan gereja Advent mengenai pembenaran karena iman yang membunyi kaitanya dengan konsep keselamatan. Gereja Advent mengakui bahwa keselamatan bisa hilang sewaktu-waktu, sebab gereja Advent mengakui bahwa orang percaya memiliki kehendak bebas untuk memilih dan menetapkan untuk percaya kepada Kristus atau menolaknya. Dan hal ini juga akan memberi dampak yang kurang baik mengenai pembenaran, sebab gereja Advent mengakui bahwa pembenaran bisa terjadi atas usaha manusia semata.

Berbeda dengan kaun Injili yang mengakui bahwa pembenaran merupakan anugerah dari Allah kepada umat yang percaya dan mau untuk menerima pribadi Yesus Kristus sebagai Juruslamat umat manusia. Bagi kaum Injili pembenaran adalah hal yang positif yang harus diterima oleh setiap individu, ketika orang percaya menerima Yesus Kristus dalam hidupnya maka dengan sendirinya orang percaya telah dibenarkan dari dosanya, jadi pembenaran orang percaya di hadapan Allah sifatnya kekal. 2

\section{Referensi}

Bromiley W, Geoffrey. Theological Dictionary of the New Testament, Germany: British Library cataloguing in Publication Data, 1992.

Eldon, Ladd. Teologi Perjanjian Baru, Bandung: Kalam Hidup, 1999.

Enss Paul, The Moody Hand Book of Theology

Ferguson, Sinclair. The Cristian Life: A Doctrinal Introduction Carlisle, P A: Banner of Truth Trust, 1989.

Guthrie, Donald. Teologi Perjanjian Baru II, Jakarta: BPK Gunung Mulia.

Hoekema, Anthony. Saved by Grace Grand Rapids, Ml: B.Eerdmans Co., 1989.

Hakh, Samuel Benyamin. Damai Itu Meneduhkan. Bandung: Jurnal Info Media.

Idrus, Fahmi. Kamus Lengkap bahasa Indonesia, Surabaya: Greisinda Press.

J.I Packer, Evangelical dictionary of Theologi. 
Jurnal Luxnos Vol. 4, No. 2, Edisi Agustus - Desember 2018 